\title{
The Urban Expansion of Mallawi during the 19th and 20th Centuries AD (A Historical Study)
} \author{
Rafat M. EI Nabarawic,

\section{Keywords}

Mallawi
Expansion
Development's Stages
Urbanization

Reda Mamdouh Mohammed ${ }^{\mathrm{a}}$

${ }^{a}$ PhD Researcher, Tourism Guidance Department, Faculty of Tourism and Hotels, Minia University

${ }^{b}$ Professor, Tourism Guidance Department, Faculty of Tourism and Hotels, Minia University

${ }^{c}$ Professor, Islamic Archaeology Department, Faculty of Archaeology, Cairo University.

\begin{abstract}
Egypt is rich in archaeological and historical monuments, which were built in different ages and found in many cities and villages. Theses monuments range from temples and tombs to domestic properties like houses and historical palace. The urban and rural centers in which these monuments were built, i.e. cities, towns, and villages, underwent essential changes in its urban or rural topography and landscape through the different epochs of its construction and development history. This article attempts to shed the light on the transformation of the city during the 19th and 20th centuries of our common era. It focuses mainly on the natural and human factors, which played a main role in the urban transformation of the city during this critical yet important period of the modern history of Egypt.
\end{abstract}




\section{The objectives of the study:}

This article aims at achieving the following objectives:

- To highlight the transformation of Mallawi during the 19th and 20th centuries AD.

- To fully explore the natural and the human factors, which played a decisive role in the urban transformation of the city.

- To identify the factors that actively contribute to urban transformation of the city.

\section{Introduction}

Mallawi is located about 38 kilometers south of Minia in Middle Egypt (Fig. 1). It is one of the most important commercial and populace cities in Minia; it is also famous with a large number of monuments and tourist sites, ranging from ancient monuments to modern attractions. It was known in ancient Egypt texts as Mrw, which literally means 'the store'. Later on, the word Mrw was transformed into Maroe, and Manlawy in Coptic texts, and then Manlawy El Arish in modern times. Mallawi is one of the largest cities in Minia with more than 80 villages under its administrative supervision ${ }^{1}$.

Historically and geographically speaking, Mallawi has been an administrative part of the Hermopolite nome, which was named after Greek assimilation of the god Herms with the god of the Hermopolite nome, the Egyptian Thoth, God of reckoning and wisdom. The capital of the nome was Hermopolis Magna, which is the ancient Egyptian Khemenu and the modern village of Al Ashmonin. Mallawi continued to belong administratively to the Hermopolite nome in the Ptolemaic and Roman periods. In the Byzantine age, the dioceses of Hermopolite nome was included into the Diocese of Lower Thebes, with Antinoopolis (moden El Sheikh Abada) as it headquarter ${ }^{2}$. Mallawi notably includes a large number of Christian monuments, the majority of which were built on west bank of the Nile. On the northwest of Mallawi there is the village of Hor, which has a church named after Malak, and west of it there is Deir Abou Fana. On the east bank of the Nile in the north there is a large number of monasteries, such as El Deir, Sonbat and El Nasara. There is the district of El Sheikh Abada, which has monuments dating back to the Ptolemaic and Roman periods.

Belong to Mallawi also are Deir Abou Henes and Youhina El Qoseir, the house of Maria El Qabtya, the wife of prophet Mohamed (peace be upon him), the mosque of El Sheikh Abada Ibn Al Samet and the district of Deir El Barsha. It is worth mentioning that Mallawi was visited by a number of the prophet's companions, notably Shiekh Abda ibn Al Samet who has a mosque named after him. ${ }^{3}$

Deir El Malak in Rirmon is located on the west side of the Nile opposite Deir El Barsha $^{4}$. There is also El Sheikh Said district of Mallawi, which is situated on the west bank of the Nile, and has a museum. To Mallawi also belong the well-known sites of Al Ashmonin and Tuna El Gebal, which are located on the west of Mallawi and possess many monuments 5 .

In 1992, the relics of Appa Ban (Abu Fana) were discovered at the site of Abu Fana. They are now kept in the Cathedral of Mallawi ${ }^{6}$. In the Islamic period, Mallawi became one of the villages of $\mathrm{Al} \mathrm{Ashmonin,} \mathrm{but} \mathrm{in} \mathrm{1721,} \mathrm{during} \mathrm{the} \mathrm{rule} \mathrm{of} \mathrm{Mohamed} \mathrm{El}$

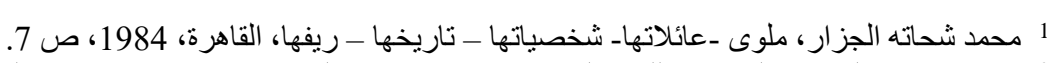

2 محمد رمزي، القاموس الجغر افي للبلاد المصرية منذ عهد قدماء المصرين حتي عام 1945م، القسم الثاني البلاد الحالية، القاهرة، ج4،

${ }^{3}$ Yehia,E. F. 2015. 'Mallaw" Did it deserve to be the Capital of El Farouqia', Journal of the Faculty of Tourism and Hotels, the Fayoum University, vol. 9, no.2.2, 123.

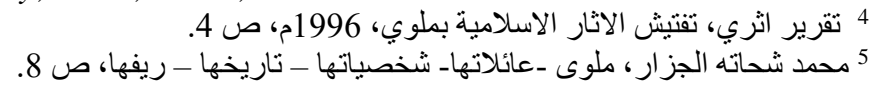$$
{ }^{6} \text { Yehia, 2015, } 124 .
$$ 
Nashangy, the center of guardianship moved from Al Ashmonin to Mallawi, as it was nearer to the Nile. In 1722, the guardianship of Al Ashmonin was called Al Ashmonin directorate, and in 1787 the north part of this directorate which included Minia and Abou Korkas was administratively separated, and half of the north of Bahanwsya was added to it. The southern half of Al Ashmonin directorate, which included Mallawi, was added to Manflout directorate and then to Asyut directorate in 1823. Mallawi became an independent center in 1890, with Mallawi as its capital. It has always been famous for sugar manufacturing ${ }^{7}$.

Perhaps the best-known historical event occurred in Mallawi is the visit by the Holy Family during their flight in Upper Egypt. The Holy Family disembarked first in Roda and then proceeded to Hermopolis Magna, and then they went to Mallawi and stayed there for many days 8 .

Mohamed Ali, the founder of modern Egypt, made Mallawi a center for supplying Egyptian armies with weapons, and established factories for making fabrics known as El Malty. He also established sugarcane factories in Rirmon, which produced 12195 quintals of raw sugar. There was another factory for sugar in Rowda, the river port of Mallawi, in which he constructed a gunpowder factory to serve the army in $1833^{9}$. It was Khedive Ismail who gave his order to establish Rowda town on the west bank of the Nile. During the reign of King Fouad, Mallawi was chosen to be a center for agricultural experiments in Middle Egypt, with a world-class farm. Ali Pasha Mubarak described Mallawi as an ancient village in Upper Egypt which had shops, coffee bars, palaces, wide streets and fountains, known for making cotton sheets. Khedive Ismail's care for the town is best understood through his orders for buildings waters channels, canals and bridges. According to Ali Pasha Mubarak, Mallawi was inhabited by nobles ${ }^{10}$.

Mallawi has always played an important role in the economic life of Upper Egypt, as it had tanneries and factories. The industrial and commercial prosperity of Mallawi led to high standard of living of its people, something that is manifest in the construction and luxury of th inhabitants' domestic properties, especially palaces. During the first half of the twentieth century, the urban structure of Mallawi expanded on the west; the city's landscape also extended on its north side in the same century. A museum of monuments was established in 1961, and was officially inaugurated on 23 July $1963^{11}$.

\section{The Urban Expansion of Mallawi:}

There are two important factors influencing the urban expansion of Mallawi: the digging of the Ibrāhimiyya Canal and the erection of the railway station.

\subsection{The Digging of the Ibrahimyah Canal}

The Ibrahimyah Canal is an irrigation canal that was dug in the reign of Khedive Ismā' $\overline{1}$ in 1284-1290 A.H./ 1867-1873 A.D. This 267 kilometer long canal is used to take off the Nile water without any weirs or inlet works on the river (the water of the river entered it freely) to irrigate the agricultural lands in many governorates. This canal has its head on the left bank of the Nile, opposite Asyut governorate, and ends in "Ashmant"

\footnotetext{
${ }^{8}$ Yehia, 2015, 124.

9 Yehia, 2015, 125.

10 ابن بطوطه، تحفة الانظار في غرائب الابصار وعجائب الاصفار المعروف بالرحلة، تحقيق أحمد العوامري ومحمد أحمد جاد

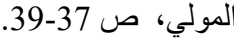
11 عبد الرحمن الر افعي، سعيد عبد الفتاح عانشور، مصر في العصور الوسطي بين الفتح العربي وحتي الغزو العثماني، القاهرة، 1992م، 
in Bani Sueif governorate. It was designed by the genius Egyptian architect Mustafa Bahjat Pasha ${ }^{12}$.

The digging of the Ibrahimyah Canal in 1290 A.H. /1873 A.D. made a natural boundary between the west and east halves of Malawi. During that time, the means of transportation were quite simple, and there were no bridges to connect the two sides of the city. The only means of transport from the east to the west side of Mallawi was boats, which were not effective in transporting large number of people and goods. As a result, the urban expansion of Mallawi has focused for a long time on the narrow strip, which is bounded by the Nile on the east and the Ibrahimyah Canal on the west. Undoubtedly, the Ibrahimyah Canal had a prosperous economic impact on the city, where the agricultural lands on the west side of the city were under perennial irrigation and exclusively depended on this canal for the provision of their water resources. ${ }^{13}$

\subsection{The Erection of the Railways (PL. 4) ${ }^{14}$}

The erection of the railways, which directly and rapidly connected Mallawi with other provinces and settlements, has a measurable effect on the city's urban expansion. The city has since become an accessible destination for merchants, who used the railways for coming and going out of the city, whether for trade purposes or settlement. Most of the modern constructions, which followed the western European style of architecture and decoration, were built in the city after the construction of the railway, though similar buildings were built in Cairo and Alexandria since the reign of Muhammad 'Alī Pasha. ${ }^{15}$ Mallawi railway station has always been one of the three most important stations in Minia governorate, namely Maghagha, Minia, and Mallawi. ${ }^{16}$ It is worth noting that Orabi Pasha attended the station's opening ceremony on July 30, 1882 AD. It was built after the British style, and was continuously sustained until $2000 \mathrm{AD}$, when it was completely redeveloped into a new style. It was official reopened in 2004 AD as part of the reconstruction plan of Egypt's national railways. ${ }^{17}$

\subsection{The Stages of Urban Development of Malawi}

The urbanization of Malawi has underwent four stages of development, as follows ${ }^{18}$ : The first stage: Prior to 1900

The second stage (1900-1954)

The third stage (1954-1990)

The fourth stage (1990-2007)

\subsection{1: The First Stage: Prior to 1900 (Fig. 2)}

\footnotetext{
${ }^{12}$ Mohamed, N. W. 2013. El Minia City during the Reign of Mohamed Ali and his Dynasty, Unpublished $\mathrm{PhD}$ Dissertation, Faculty of Tourism and Hotels, Minia University, Minia, 155.

${ }^{13}$ Mahn, D. M. 1998. Spaces of poverty: The Geography of social change in Rural Egypt, Directions of Change in Rural Egypt, AUC Press, Cairo, 260.

${ }^{14}$ Egypt is noted for the early development of its railways. The plan had been under consideration from 1266 A.H./1849A.D., and in 1267 A.H./ 1851 A.D. "Robert Stephenson", son of the inventor of steamdrive, was granted a concession for the construction of the line from Alexandria to Suez via Cairo. While the track linking Alexandria to Cairo was completed in 1272 A.H./ 1856 A.D., the railway to Suez via Zaqāzīq and Ismā îliyya was only ready for the inauguration of the canal in 1286 A.H./ 1869 A.D. These two developments made up a part of the broader Delta Railways, which had been developed by the khedive Ismā' $\overline{1}$ l and had brought the total distance of track laid to 1,338 kilometers. The AlexandriaCairo junction was followed by the construction of Upper Egypt railways, where in 1307 A.H./ 1890 A.D. This line reached Aswan. See, Martinidis, V. H. 2003. The Advent of Transport and Aspects of Urban Modernization in the Levant during the Nineteenth Century: The City and the Railway in Europe, Ashgate Publishing, Ltd., 64.

${ }^{15}$ Mohamed, 2013. El Minia City during the Reign of Mohamed Ali and his Dynasty, 57.

${ }^{16}$ Mohamed, 2013. El Minia City during the Reign of Mohamed Ali and his Dynasty, 156.

${ }^{17}$ Mahn, 19908. Spaces of Poverty, 262.
}

18 الهيئة العامة للتخطيط العمر اني، المخطط الاستر اتيجي لمدينة ملوي، ص 25. 
The first map of Mallawi made its appearance at the beginning of the twentieth century, specifically in 1900 , when the map scale of $1 / 5000$ points out that the city center was located on the west bank of the Ibrahimyah Canal. In this way, Mallawi looked like the old centers of ancient Egyptian towns, which were located near the River Nile. ${ }^{19}$ During that time, many buildings were surrounded with Dair Al Nahyah Road, which was built to protect them from the furious Nile flood. Mallawi's urban construction at that stage combined huge constructions and narrow streets. The urban area at that stage occupied approximately 132,9 acres, representing $15 \%$ of the urban area in 2007. According to estimates, the total number of Mallawi's population during that stage was 8 thousands, with a population density of about 60,2 person per acre. ${ }^{20}$

\subsection{2: The Second Stage (1900-1954):}

During that stage, the town witnessed development projects in almost all fields, where the urban development of Mallawi went beyond the Ibrahimyah Canal and the city for the first time expanded on the north-east. Yet urban extension at that stage was largely focused on the north-west side of the city. During that stage, the urban mass of the city increased 206 acres, which means that Mallawi managed to include in its urban environment nearly 5.1 acres per year. As for the population, it is estimated that there were 26000 inhabitants, with an annual increase of $3 \%$. The population density at that stage is estimated at 76.7 persons per acre, which did not greatly differ when compared to the population density of the preceding stage.

\subsection{3: The Third Stage (1945 -1990) (Fig. 3):}

During that stage, Mallawi witnessed a notable urban development, which was concentrated basically on the western side of the town. Totally, the urban area increased by363 acres at that stage, with an annual increase of 9.1 acres. The population density hugely increased to be 142,5 persons per acre, with a total population of 100 thousand people.

\subsection{4: The Fourth Stage (1990 -2007) (Fig. 4):}

During that stage, the city of Mallawi underwent huge project of urban development, where the land capacity occupied 184.1 acres in 17 years, with an annual increase ratio of about 10, 8 acres. It is worth noting that the laws prohibiting the construction on agricultural lands, which were formulated by the vice military ruler during that stage, were not decisive in limiting the random construction on agricultural lands. Given that the town of Mallawi is surrounded by fertile lands, and taken into account that there was no official plan for the town's urban development, the inhabitants continued to build randomly on the surrounding agricultural lands in Mallawi. So, the urban development at that stage was a random development without building licenses. According to the population census of 2006, the population of Mallawi reached 140 thousand people, making that stage the largest population density of the town that reached 160 persons per acre. At that stage, the town's population doubled 17 times, and the urban area of the town doubled 7 times (Fig. $5 \& 6)^{21}$.

\subsection{The Contributing Factors to the Urban Development of Mallawi:}

A number of geographical and administrative factors were decisive in the town's urban extension. These factors will be discussed in the following section.

\section{- The Geographical Location:}

Malawi is located $45 \mathrm{~km}$ south of Minia governorate in the flood plain on the west bank of the River Nile; it is situated at the intersection of the longitude $50^{\circ} 30$ East and the

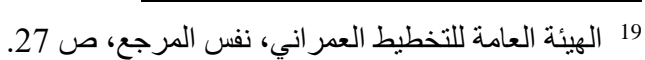

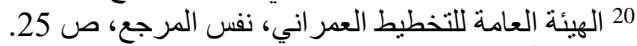

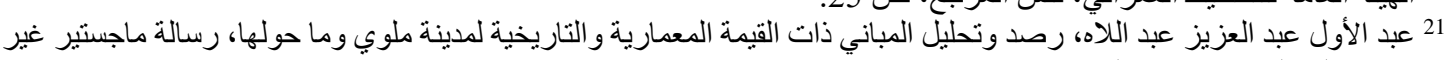

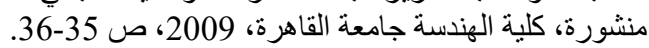


latitude $27^{\circ} 44$ West. It is flanked between Abu Korkas $11 \mathrm{~km}$ on the north and Dair Mouas $11 \mathrm{~km}$ on the south. It is connected to other towns by the national agricultural road and the railway, which connect Cairo, the capital, with all Upper Egyptian governorates. ${ }^{22}$. It is $170 \mathrm{~km}$ south of Bani Suif, and the distance between Malawi and Cairo is about $292 \mathrm{~km}$. The Cairo- Aswan railway line passes through Malawi, in addition to the Cairo- Aswan Agricultural Road. Also, the Desert Road (Cairo- Asuit) passes on its western side. The importance of this location increases due to the development and influx of transportation means, such as land roads, railways, and the River Nile. This accelerates the urban development of Malawi ${ }^{23}$.

- The Population:

There is a direct correlation between the size of Mallawi and the number of its population. The more the number of its population, the more the size of the city was. In other words, size of Malawi has rapidly increased to meet the increasing number of its population. Malawi is one of the largest cities in Middle Egypt. Due to the higher standard of living than its surrounding villages, a number of the inhabitants of the latter had migrated to live in the city. Such an immigration appears during the first stage of the city's urban development, when most Pashas, who were perhaps the richest landlords in the region, left their villages and lived in Malawi like the family of Sief Al Nasr Pasha, who moved to Mallawi from Dirout Om Nakhlah. These movements of village immigration to the city lead to the increase in the city's land size and urban extension.

\section{- The Industrial Development:}

Like the location and population, the industrial development in the city has an influential impact on its urban development, which can be summarized as follows:

1- The industries and professions that were spread in Malawi had attracted manpower from other nearby rural areas. This results in the extension of city and the increase in the number of its population, which represents $16,81 \%$ of the total number of the inhabitants of Minia governorate.

2- Industrial activities in Mallawi led to a boom in productivity and salary rates. The ensuing increase in the purchase power had resulted in commercial prosperity and the extension of the town's size and the reproduction of its population.

3- The industrial establishments in Mallawi, including tanneries and cotton ginneries, helped increase the town's size, which extended on the south-west side.

The previously mentioned factors helped increase the size of Malawi and its commercial and urban development, making it the second largest town in the country after Al Mehalah Al Kobra, of course with the exception of the capitals of the governorates.

\section{5: The Morphology of Mallawi $^{24}$ :}

According to its urban formation and general appearance, Malawi can be divided into five sections:

\section{The Old Area on the west of Malawi Railway Station:}

The area on the west of Malawi Railway Station is the oldest downtown. It is marked with its ancient lookout and buildings, which are found in the old area of the town, the town center, and the old commercial center. These buildings are located at the heart of the urban area. The Railway Station played a vital role in this formation, as the old town is located next to the railway station.

\footnotetext{
${ }^{24}$ The term morphology refers to the urban formation of towns.
} 
Services are located on the middle, eastern, and western areas. The services are divided into three sections. The first is the central area in downtown, and it represents the main and first center for services in the town. The second is the eastern area to the east of the Railway Station; it mainly represents educational services and is built in modern times at the town's suburbs. The third section is the western area to the west of the Dirottyah canal; it is a modern area at the town's suburbs, where medical and educational services are concentrated ${ }^{25}$.

The rural area is the southern area of the town, which is distinguished by its rural random appearance. The commercial area is located in downtown. It is an area where modern buildings are located, and where housing and commercial uses are prevailing. It represented a distinguished visual expression in the town, where commercial districts, malls and markets on the 26th of July Street are found. The marginal, randomly extension areas are located at the outskirts of the city. They are characterized by the presence of unplanned slums, where buildings are built on agricultural lands in the suburbs.

\section{Conclusion:}

Mallawi has always enjoyed high importance in modern Egypt as it may reflect some aspects of the country's economic and cultural development. The city has a large number of monuments, dating back to various periods of Egyptian history, including ancient Egyptian, Graeco-Roman, Byzantine, Coptic, and Islamic architecture. Malawi underwent many developments in its urban morphology and landscape through ages. The south-north direction along the Ibrahimyah canal and the Cairo- swan railway line is the most enduring in the city's development. In the north-west direction of the 1950s, the urban extension went beyond the Ibrahimyah Canal. In the north-west extension, however, the urban development extended in the direction of the agricultural lands. Malawi has experienced four stages of urban development. The first stage, before 1900, witnessed the formation of the old downtown on the west bank of the Nile, where buildings were surrounded by Dair Al Nahayah Road, which was constructed for protection of the city against the furious annual Nile flood. Also, the urban layout of that stage is characterized with narrow, zigzag streets. The second stage, which extends from 1900 to 1954, witnessed the town extension in almost all directions, as the urban extension went beyond the Ibrahimyah Canal in the north-east direction of the town, while the largest urban extension remains in the north- west direction. The population of Malawi during this stage reached 74 persons per acre. The third stage, which extends from 1954 to 1990, is characterized with urban extension at the external surroundings on the western side of the town. In the fourth stage, from 1990-2007, the town was largely extended and reached 184.1 acres through 17 years, with an annual development ratio of 10, 8 acres per year, while the urban development at that stage was randomly. A number of important factors contributed to the urban development in Malawi, including the geographical location, the population, and the immigration from the surrounding villages in addition to the industrial activities.

\footnotetext{
${ }^{25}$ Gaffney, P. D. 1997. Fundamentalist Preaching and Islamic Militancy in Upper Egypt. Spokesmen for
} the Despised: Fundamentalist Leaders of the Middle East, University of Chicago Press, 265-266. 


\section{Bibliography:}

• محمد شحاته الجزار، ملوى -عائلاتها- شخصياتها - تاريخها - ريفها، القاهرة، 1984.

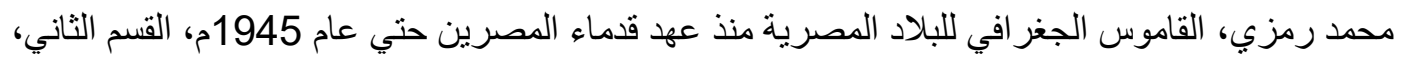

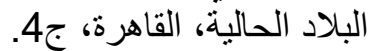

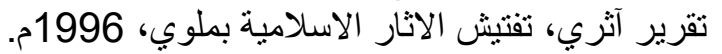

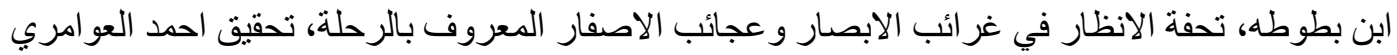
ومحمد احمد جاد المولي.

عبد الرحمن الر افعي، سعيد عبد الفتاح عاشور، مصر في العصور الوسطي بين الفتح العربي وحتي الغزو العثماني، القاهرة، 1992م. الهيئة العامة للتخطيط العمر اني، المخطط الاستر اتيجي لمدينة ملوي.

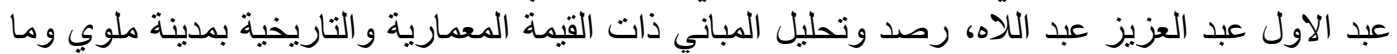
Foreign references: حولها، رسالة ماجستير، كلية الهندسة، جامعة الاز هر، ريذ 2009.

- Gaffney, P. D. 1997. Fundamentalist Preaching and Islamic Militancy in Upper Egypt, "Spokesmen for the Despised: Fundamentalist Leaders of the Middle East", University of Chicago Press.

- Mahn, D. M. 1998. Spaces of Poverty: The Geography of Social Change in Rural Egypt, Directions of Change in Rural Egypt", AUC Press, Cairo.

- Martinidis, V. H. 2003. The Advent of Transport and Aspects of Urban Modernization in the Levant during the Nineteenth Century: The City and the Railway in Europe, Ashgate Publishing Ltd.

- Mohamed, N. W. 2013. El Minia City during the Reign of Mohamed Ali and his Dynasty, Unpublished PhD Dissertation, Faculty of Tourism and Hotels, Minia University, Minia.

- Yehia, E. F. 2015. 'Mallawi: Did it deserve to be the Capital of El Farouqia', Journal of the Faculty of Tourism and Hotels, The Fayoum University, vol. 9, no. 2.2 . 


\section{ملخص البحث:}

\section{التوسع الحضاري لمدينة ملوي خلال القرنين التاسع والعشرين}

يتناول البحث تاريخ مدينة ملوي وموقعها منذ انشائها وأثر ذلك على تطور المدينة وتسميتها حتى أصبحت تعرف

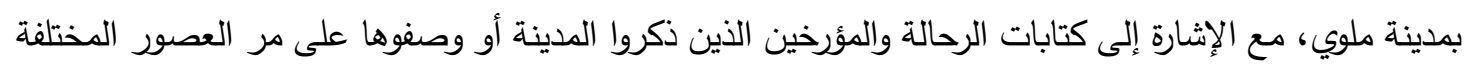

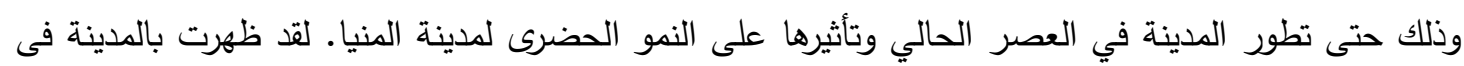

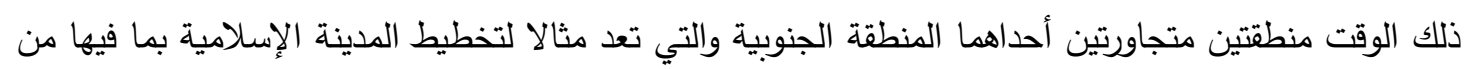

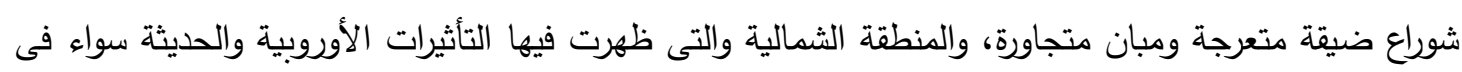

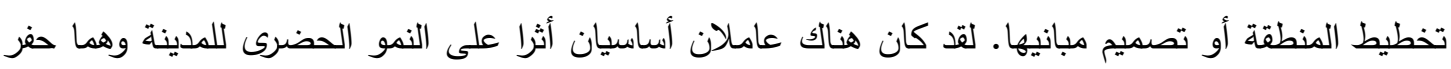

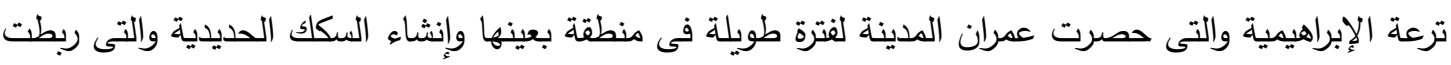

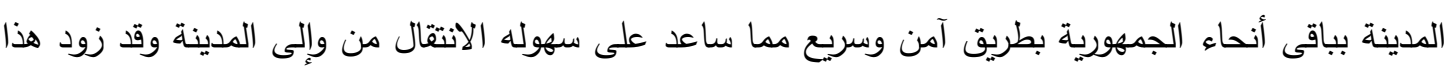

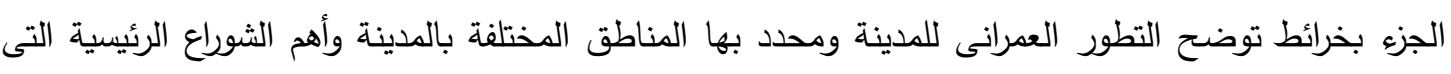
تربط مركز المدينة حاليا والذى كان هو أساس مدينة ملوي خلال القرنين التاسع عشر والعشرين. ويهدف البحث الي دراسة التغييرات التي طرأت على مدينة ملوي خلال القرنين التاسع عشر والعشرين والتين والأسباب التي أدت إليها

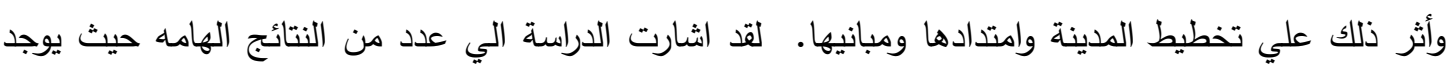

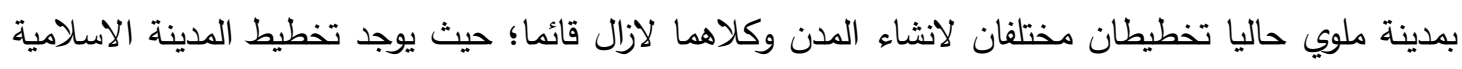

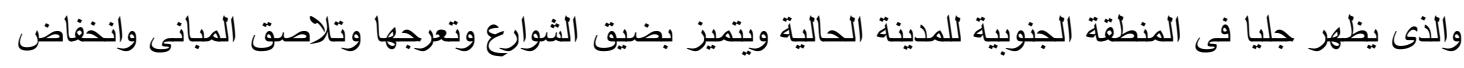

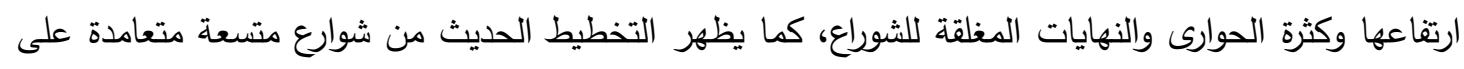
بعضها البعض والميادين الواسعة التي تحتوي على مساحات خضراء ونافورات ومبانى وقصور منفردة وغير متلاصقة حيث لكل منها أربع واجهات. لقد ظهرت بالمدينة مبانى حديثة تتبع الطرز المعمارية والفنية الاوربية وذلك نتيجة للوضع الاقتصادى المرتفع لبعض الطبقات الاجتماعية بالمدينة مثل الباشاوات والاعيان. 


\section{Plates:}

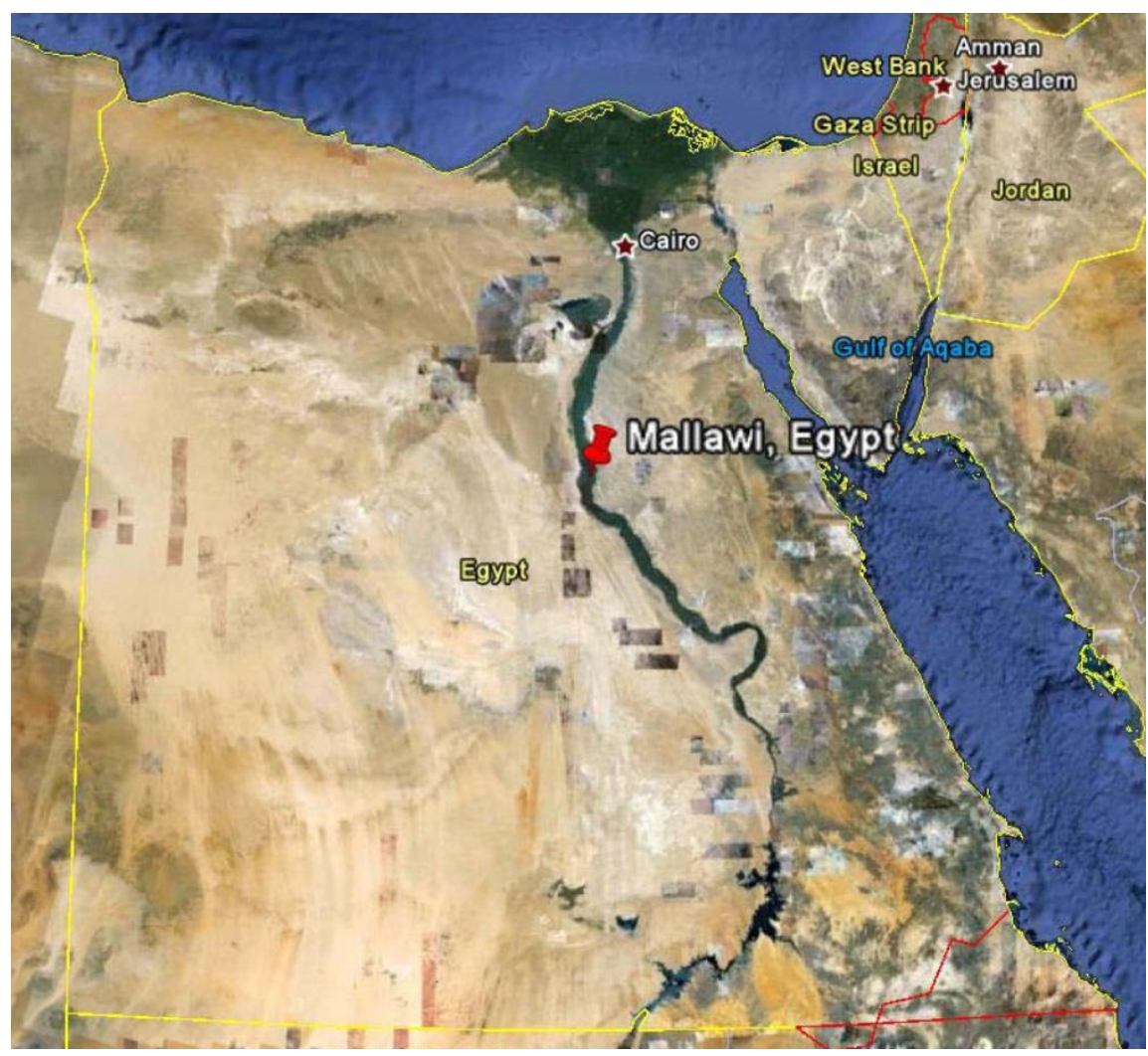

Fig. 1

Map of Mallawi in Middle Egypt

Source: https://evanstonfairtrade.files.wordpress.com/2011/07/mallawimap.jpg 


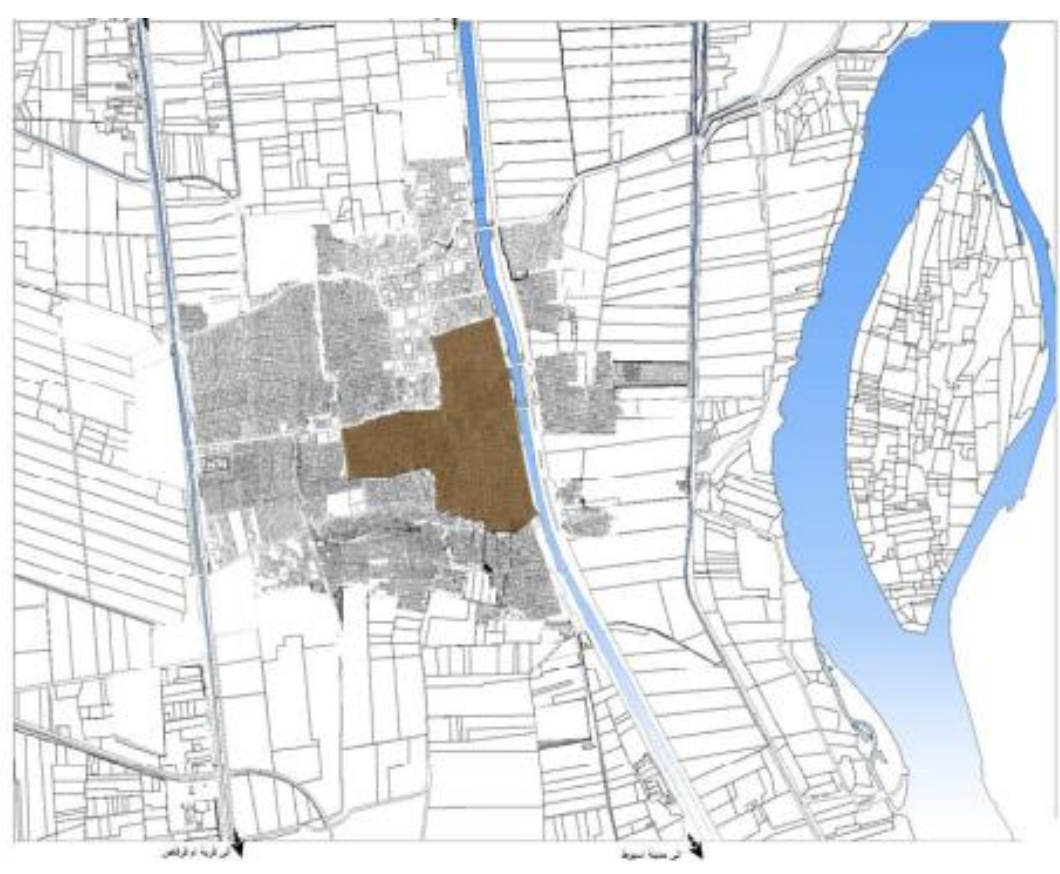

Fig. 2

Ubran development of Mallawi city the first stage before 1900 AD 


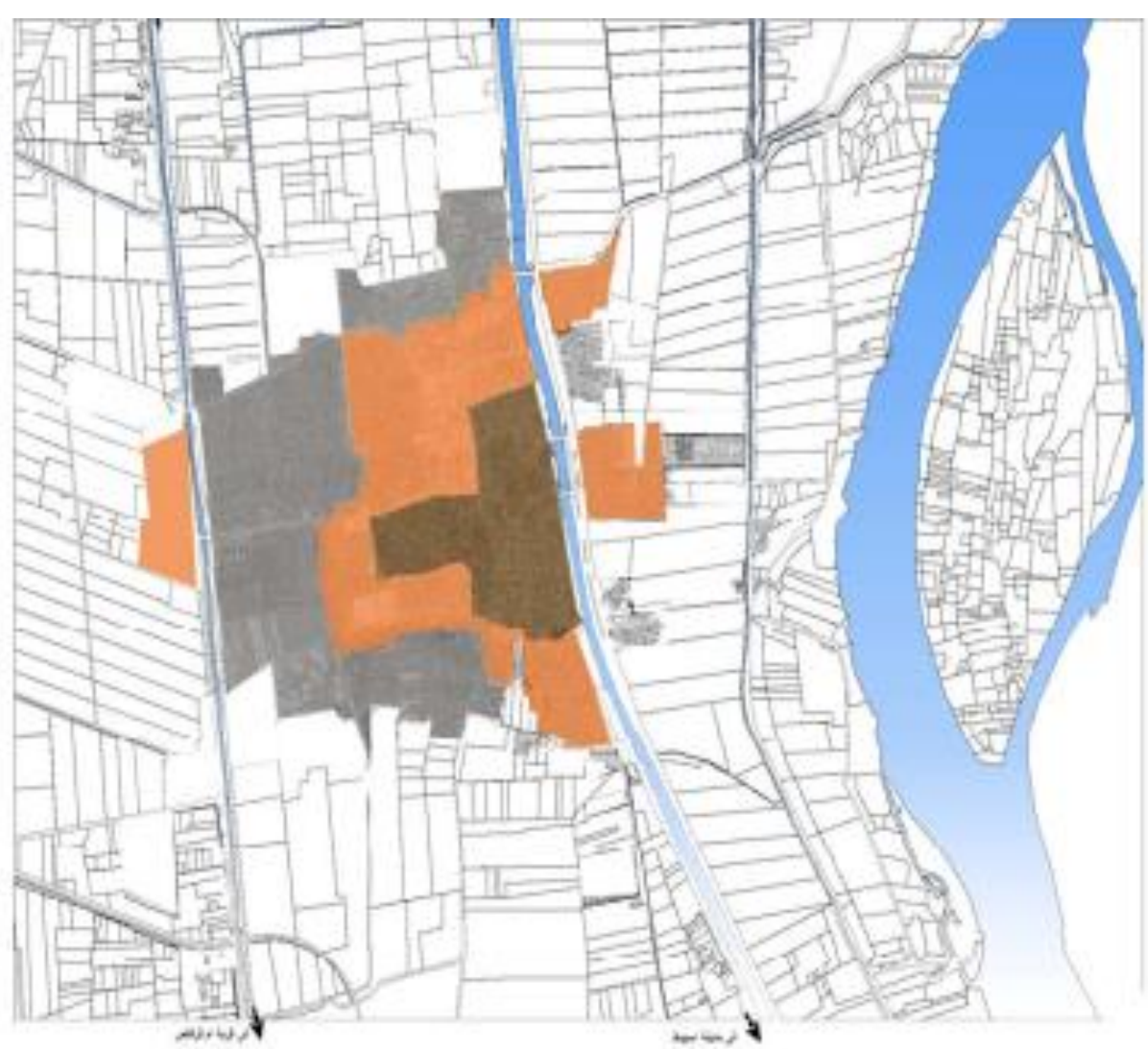

Second Stage

First Stage

Third Stage

Fig.3

Urban development of Mallwai citv between 1954 - 1990 AD

(By the Researcher) 


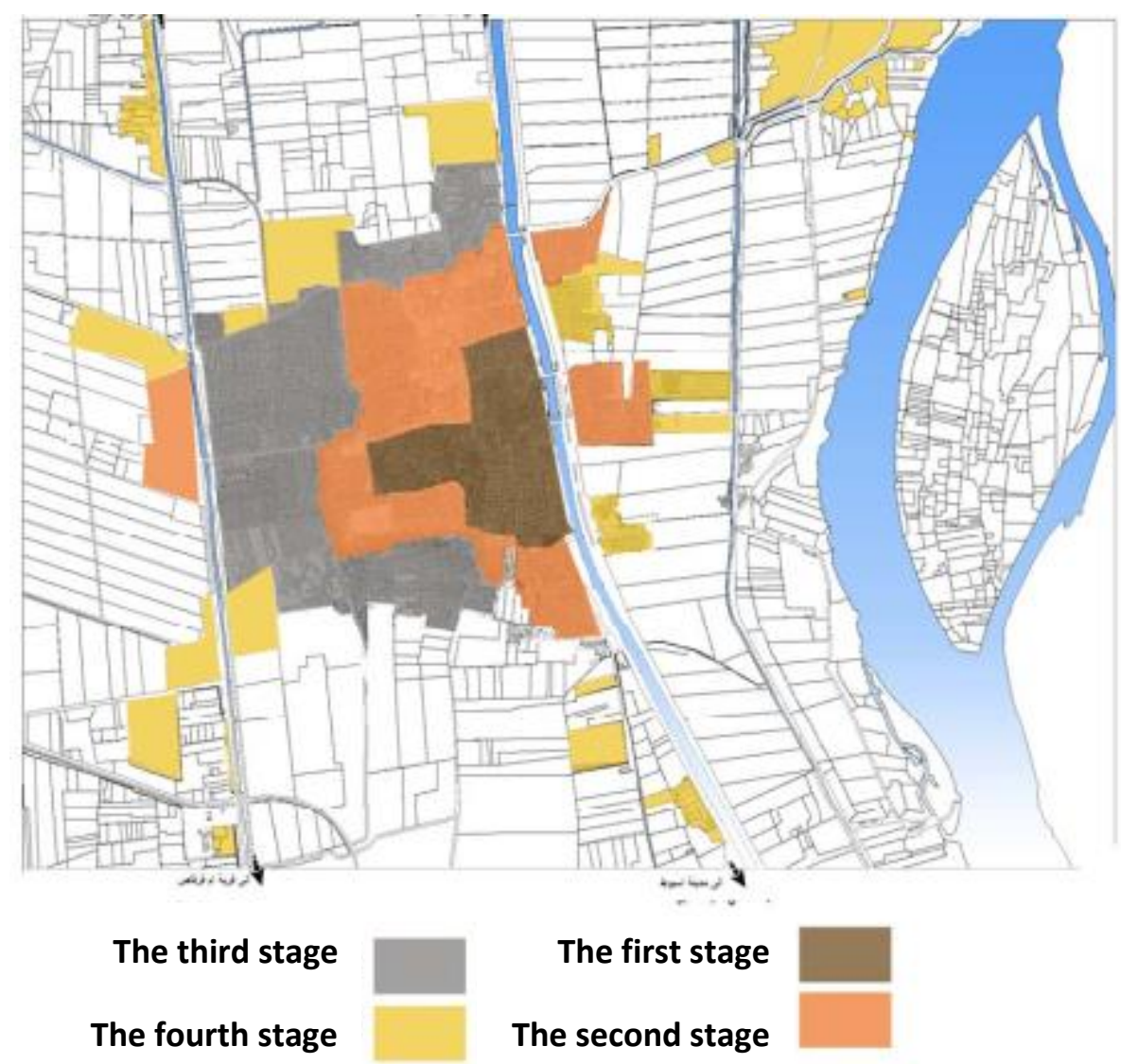

Fig. 4

Urban development of Mallawi city between fourth Stages: $1990-2007$ AD 


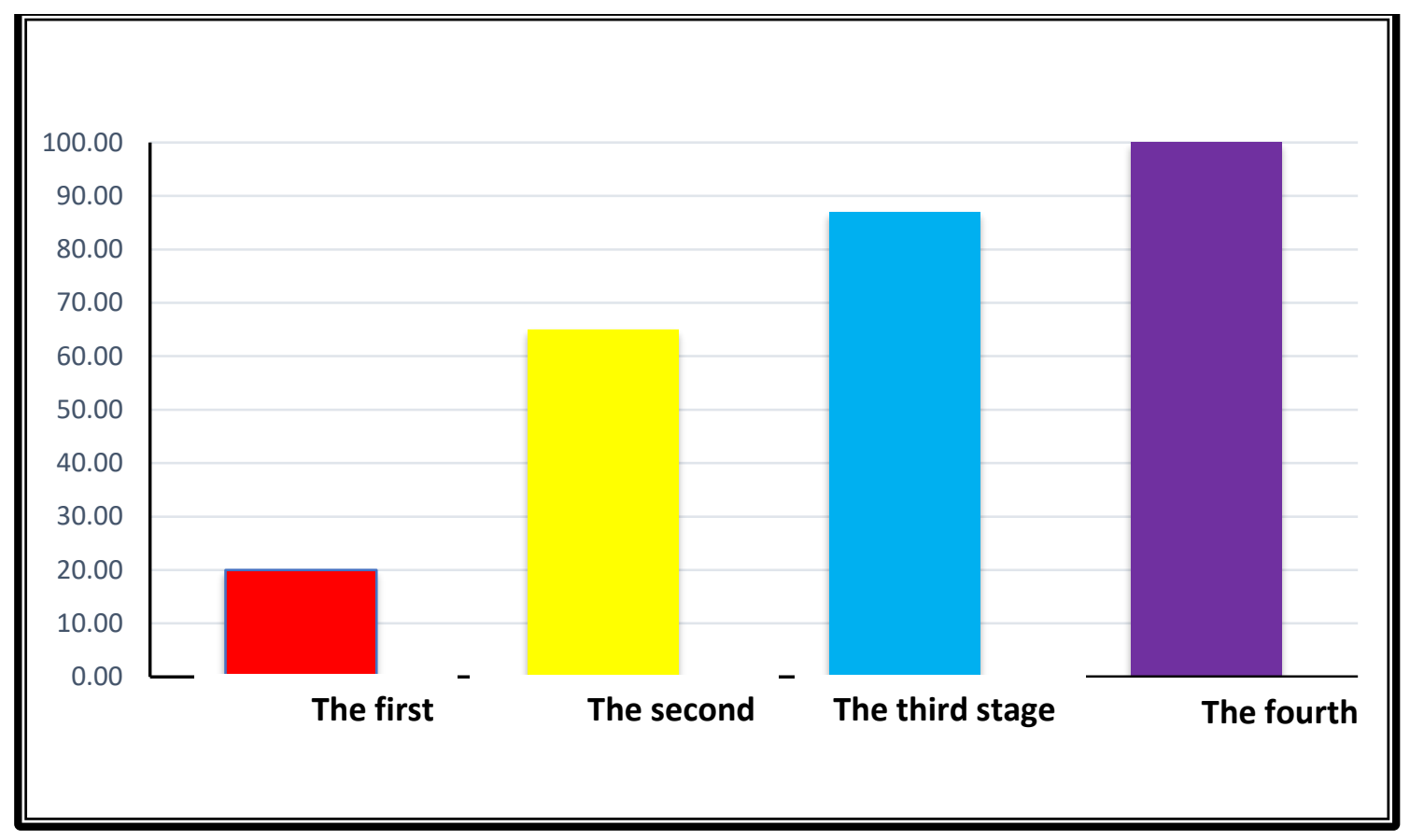

Fig. 5

Urban development of Mallawi city

(By the Researcher)

\begin{tabular}{|c|c|c|c|}
\hline Stage & Area / Acres & Population & Desity Person / Acre \\
\hline Before 1900 & 176 & 11000 & 66 \\
\hline $1900-1954$ & 440 & 35000 & 80 \\
\hline $1954-1990$ & 906 & 112000 & 140 \\
\hline $1990-2007$ & 1232 & 197120 & 160 \\
\hline
\end{tabular}

Fig. 6

Relation between the size and the number of populations in Mallawi city 